\title{
Molecular Analysis of 55 Spanish Patients with Acute Intermittent Porphyria
}

\author{
María-José Morán-Jiménez ${ }^{1}$, María-José Borrero-Corte ${ }^{1}$, Fátima Jara-Rubio ${ }^{1}$, \\ Inmaculada García-Pastor ${ }^{1}$, Silvia Díaz-Díaz ${ }^{2}$, Francisco-Javier Castelbón-Fernandez ${ }^{3}$,
} Rafael Enríquez-de-Salamanca ${ }^{1}$ (D) and Manuel Méndez ${ }^{1, *}$

1 Instituto de Investigación Sanitaria Hospital 12 de Octubre (imas12), Fundación para la Investigación Biomédica del Hospital 12 de Octubre, Centro de Investigación, Avenida de Córdoba s/n, 28041 Madrid, Spain; moranjimenez@h12o.es (M.-J.M.-J.); mjose.borrero@hotmail.com (M.-J.B.-C.); fatimatalaveranet@gmail.com (F.J.-R.); macu.garcia.pastor@gmail.com (I.G.-P.); salamanca@med.ucm.es (R.E.-d.-S.)

2 Servicio de Análisis Clínicos, Hospital 12 de Octubre, 28041 Madrid, Spain; sddiaz@salud.madrid.org

3 Servicio de Medicina Interna, Hospital 12 de Octubre, 28041 Madrid, Spain; fjcastelbon@yahoo.es

* Correspondence: mmendez@h12o.es

Received: 13 July 2020; Accepted: 10 August 2020; Published: 12 August 2020

\begin{abstract}
Acute intermittent porphyria (AIP) results from a decreased activity of hepatic hydroxymethylbilane synthase (HMBS), the third enzyme in the heme biosynthetic pathway. AIP is an autosomal dominant disorder with incomplete penetrance, characterized by acute neurovisceral attacks precipitated by several factors that induce the hepatic 5 -aminolevulinic acid synthase, the first enzyme in the heme biosynthesis. Thus, a deficiency in HMBS activity results in an overproduction of porphyrin precursors and the clinical manifestation of the disease. Early diagnosis and counselling are essential to prevent attacks, and mutation analysis is the most accurate method to identify asymptomatic carriers in AIP families. In the present study, we have investigated the molecular defects in 55 unrelated Spanish patients with AIP, identifying 32 HMBS gene mutations, of which six were novel and ten were found in more than one patient. The novel mutations included a missense, an insertion, two deletions, and two splice site variants. Prokaryotic expression studies demonstrated the detrimental effect for the missense mutation, whereas reverse transcription-PCR and sequencing showed aberrant splicing caused by each splice site mutation. These results will allow for an accurate diagnosis of carriers of the disease in these families. Furthermore, they increase the knowledge about the molecular heterogeneity of AIP in Spain.
\end{abstract}

Keywords: porphyria; acute intermittent porphyria; hydroxymethylbilane synthase; porphobilinogen deaminase; mutation analysis; splicing defect; prokaryotic expression

\section{Introduction}

Acute intermittent porphyria (AIP; OMIM 176000) is the most common acute hepatic porphyria, and is inherited as an autosomal dominant trait with incomplete penetrance [1]. AIP results from a partial deficiency of hydroxymethylbilane synthase (HMBS; EC 4.3.1.8), also named porphobilinogen deaminase (PBGD), the third enzyme in the heme biosynthetic pathway. Human HMBS is a cytoplasmic monomeric enzyme that catalyzes the polymerization of four porphobilinogen (PBG) molecules to form a linear tetrapyrrole (hydroxymethylbilane), using the dipyrromethene cofactor $[2,3]$.

The disease is more frequent in women than in men, and usually manifests during or after puberty, with recurrent acute attacks with neurovisceral manifestations, including abdominal pain, vomiting, constipation, hypertension, tachycardia, peripheral neuropathy, and psychiatric disturbances [1]. 
Acute attacks are triggered by several factors, including steroid hormones, certain drugs, alcohol, and fasting, which induce hepatic 5-aminolevulinic acid synthase (ALAS1), the first and rate-limiting enzyme in the heme biosynthesis [1]. The increase in ALAS1 activity enhances the production of porphyrin precursors, 5-aminolevulinic acid (ALA), and PBG [1,4]. Then, a deficiency in the activity of hepatic HMBS causes an overproduction and massive urinary excretion of ALA and PBG, along with clinical manifestations [1,4]. Therefore, early diagnosis and counselling regarding precipitating factors is essential to manage and prevent acute attacks in symptomatic patients and in latent heterozygous relatives. During an acute attack of AIP, patients excrete high amounts of precursors, and the urine is positive for the qualitative detection of PBG by means of the Hoesch test [5]. In urine, PBG spontaneously polymerizes to uroporphyrin and, therefore, patients with AIP excrete an increased amount of uroporphyrin [6].

The human HMBS gene has been mapped to the chromosomal region 11q24.1-q24.2, spanning a genomic interval of $10 \mathrm{~kb}$. It contains 15 exons and produces two mRNA transcribed from different promoters, the housekeeping (in $5^{\prime}$ end untranslated region) and the erythroid-specific (in exon 1), which encode the ubiquitous and erythroid isoforms, respectively [7-9]. The housekeeping mRNA contains exon 1 joined to exons 3-15 with the translation start codon in exon 1 , and encodes an enzyme that contains 361 amino acids ( 42 KD), whereas the erythroid-specific mRNA contains exons 2-15 with the translation start site located within exon 3, and it encodes an enzyme of 344 amino acids ( 40 KD) $[10,11]$. The crystal structure of the ubiquitous human HMBS reveals that it consists of three distinct $\alpha / \beta$ domains of a similar size, with the active site between domains 1 and $2[2,3,12]$.

Two subtypes of AIP have been described, a classical and a non-erythroid form $[1,13,14]$. In the classical AIP, the HMBS activity is reduced to about $50 \%$ of what is normal in all of the tissues, due to a mutation that affects both isoforms of the enzyme. In the non-erythroid variant AIP ( $2-5 \%$ of cases), the mutation only affects the housekeeping isoform and patients have a normal HMBS activity in the erythrocytes. In asymptomatic (latent) AIP patients, the levels of porphyrin precursors in urine may be normal [1]. The measurement of the erythrocyte HMBS activity can be used to identify these individuals, however this is limited to classical AIP. Moreover, there is a significant overlap in the activity values between the heterozygote and normal individuals [7]. Therefore, when a disease-causing mutation has been identified in a proband, a molecular analysis is the most accurate method to identify asymptomatic heterozygotes in the family $[7,15]$. To date, over 400 disease-causing mutations have been described in the HMBS gene identified in AIP patients (Human Gene Mutation Database (HGMD), http://www.hgmd.cf.ac.uk/ac/index.php).

\section{Materials and Methods}

\subsection{Patients and Biochemical Determinations}

In this report, we studied 55 unrelated Spanish patients with AIP -47 females and 8 males. The patients were diagnosed and followed up clinically at the Hospital 12 de Octubre (Madrid, Spain). They presented a clinical history of at least one acute attack associated with an increased excretion of ALA, PBG, and porphyrins in their urine. The age at the first attack ranged from 16 to 62 years. In these patients, the erythrocyte HMBS activity was measured as previously described [16]. The HMBS activity was measured using PBG as a substrate, and the product, spontaneously converted to uroporphyrinogen I, was oxidized to uroporphyrin I by light exposition and was then fluorimetrically quantified.

All of the patients gave informed consent prior to their inclusion in the study. The study was conducted in accordance with the Declaration of Helsinki and the study protocol was approved by the Ethical Committee of the Hospital 12 de Octubre (2013-0034).

\subsection{DNA Analysis}

Blood samples were collected in tubes containing EDTA, and genomic DNA was extracted using the NZY blood gDNA isolation kit (NZYtech, Lisboa, Portugal). The HMBS gene was PCR amplified 
and sequenced using the primers described [16], but without the GC clamp. All 15 exons with their flanking intron regions were amplified in five fragments, as previously described [17]. All of the mutations were confirmed on a second DNA sample. The nucleotides were numbered according to the cDNA sequence for the housekeeping isoform of HMBS (GenBank Accession Number NM_000190), in which the A of the ATG initiation codon was numbered as 1.

\subsection{RNA Analysis}

The effect of two newly identified intronic mutations (c.161-3C $>\mathrm{G}$ and c.651+3A $>\mathrm{T}$ ) on the mRNA splicing was studied by reverse transcription-PCR (RT-PCR) and sequencing. Leukocytes were isolated from EDTA-anticoagulated blood using Ficoll-Paque Plus (Amersham Biosciences, Uppsala, Sweden), and total the RNA was extracted using TRIzol Reagent (Invitrogen, Carlsbad, CA, USA). Reverse transcription was carried out with an oligo (dT) primer and eAMV reverse transcriptase (Sigma-Aldrich, Inc. St. Louis, MO, USA). Subsequently, the HMBS cDNA was amplified, and the RT-PCR products were run on an agarose gel and sequenced. For the c.161-3C $>$ G mutation, the sense primer was 5'-ATTCGCGTGGGTACCCGCAAGAGC-3' and the antisense primer was 5'-GTCCTTC AAGGAGTGAACAACC- $3^{\prime}$, whereas for the c. $651+3 \mathrm{~A}>$ T mutation, the sense and antisense primers were $5^{\prime}$-ATTCGCGTGGGTACCCGCAAGAGC-3' and 5'-TAGGCACTGGACAGCAGCAACCCA-3', respectively. When more than one band was observed, each product was cut out of the gel, purified using the GFX PCR DNA and gel Band Purification kit (GE Healthcare, Madrid, Spain), and sequenced separately.

\subsection{Prokaryotic Expression and Characterization of the Novel HMBS Missense Mutation}

The novel missense mutation was expressed in Escherichia coli strain JM109 (Promega Corporation. Madison, WI, USA) using the pKK223-3 expression vector (Pharmacia Biotech Inc., Piscataway, NJ, USA). The pKK-HMBS-wt plasmid, in which the cDNA encoding the human wild-type housekeeping HMBS, was cloned into the EcoRI-HindIII sites of the pKK223-3 and used as the normal construct [17]. The missense mutation c.294G > T (p.K98N) was introduced into the pKK-HMBS-wt by PCR-based site-directed mutagenesis [18]. To generate the mutant construct pKK-HMBS-K98N, a DNA fragment containing the nucleotide substitution with flanking KpnI and NsiI restriction sites for cloning was generated in two PCR steps (Figure 1). First, two overlapping PCR fragments containing the mutation and a restriction site were generated separately, using pKK-HMBS-wt plasmid as the template. The primer pairs for each PCR were (a) sense 5'-ATTCGCGTGGGTACCCGCAAGAGC-3' (the restriction site for KpnI is underlined) and antisense $5^{\prime}$-CACAGTGGGCAGGTCaTTCAAG GAGTGAAC- $3^{\prime}$, and (b) sense $5^{\prime}$-GTTCACTCCTTGAAtGACCTGCCCACTGTG- $3^{\prime}$ and antisense $5^{\prime}$-CCACAGCATACATGCATTCC-3' (the restriction site for NsiI is underlined); in the mutagenesis primers, the mutated base is in bold lower case letters. After purification, both PCR fragments were used together as templates in a second PCR step using the primers with restriction sites. Then, the final PCR product was digested with the restriction enzymes KpnI and NsiI (New England Biolabs, Beverly, MA, USA), and purified using the GFX PCR DNA and gel Band Purification kit (GE Healthcare, Little Chalfont, UK). After purification, this fragment was ligated into the pKK-HMBS-wt, which had been digested with the same enzymes, and the resulting plasmid was transformed in Escherichia coli strain JM109. The integrity of the expression construct was confirmed by automated sequencing.

Bacterial clones, containing either the pKK223-3 vector or any of the pKK-HMBS expression constructs, were grown to logarithmic phase and induced with $5 \mathrm{mM}$ isopropylthiogalactoside (IPTG) for $3 \mathrm{~h}$. The cells were harvested by centrifugation and washed twice with PBS. The cell pellets were resuspended in $200 \mu \mathrm{L}$ of lysis buffer (100 mM Tris-HCl buffer, $\mathrm{pH}$ 8.0, 0.1\% Triton-X 100) and disrupted by sonication. The bacterial lysates were centrifuged, and the supernatants were used as the source of the enzyme. The HMBS activity was measured as published [16]. The specific activity (SA) was calculated as nmol of uroporphyrinogen formed per hour and $\mathrm{mg}$ of protein. Four independent 
experiments were performed, and the results were averaged. The residual activity of the mutation was calculated by dividing $100 \times($ SA-SA (pKK223-3)) by (SA (pKK-HMBS-wt)-SA (pKK223-3)).

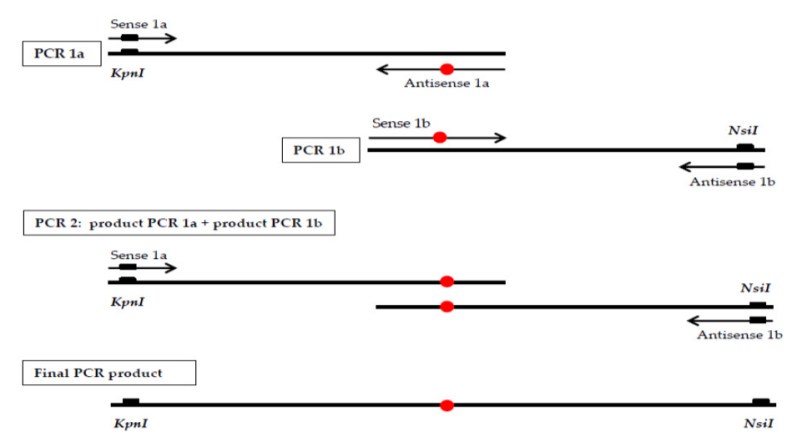

Figure 1. Two PCR steps to generate a fragment containing the c.294G > T mutation, marked with a red circle.

\section{Results}

\subsection{Patients}

Most of the patients studied displayed erythrocyte HMBS activities ranging from $24 \%$ to $78 \%$ of the control value, and one patient presented a normal activity (Table 1 and Figure 2). In each patient, we identified a HMBS mutation in a heterozygous state. Most were localized between exons 3 to 15 , except for the patient with the normal HMBS activity, which occurred in the donor site of intron 1 . Then, in this series, the classical AIP represents $98 \%$ of patients.

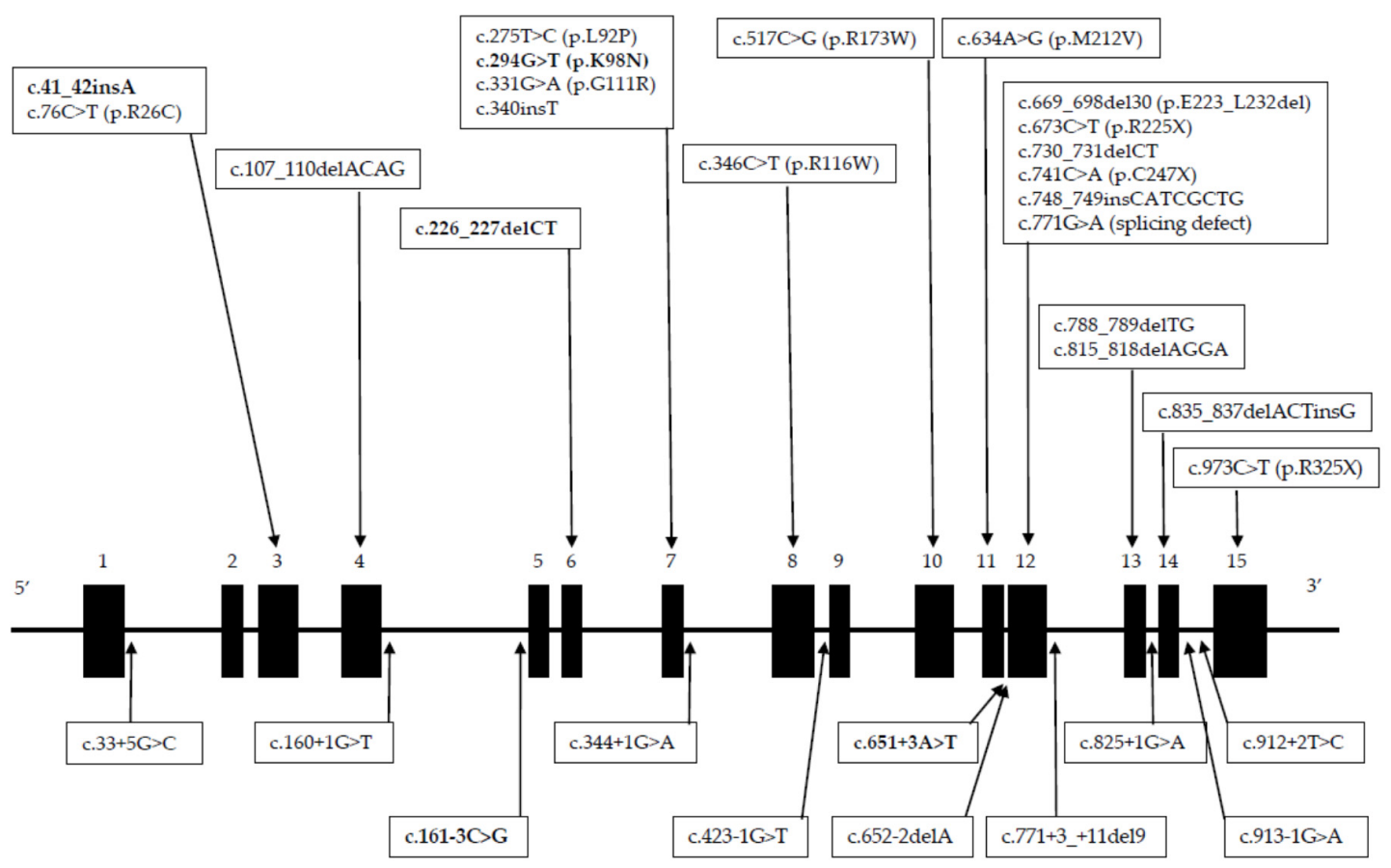

Figure 2. Diagram of locations of mutations in the HMBS gene. The black rectangles represent the exons and the lines represent the introns. Mutations found in exons and introns are shown at the top and bottom of the diagram, respectively. The novel mutations found in this study are in bold. 
Table 1. Biochemical data and hydroxymethylbilane synthase (HMBS) gene mutations identified in this study.

\begin{tabular}{|c|c|c|c|c|c|c|c|}
\hline Patient (Sex) Age ${ }^{1}$ & $\begin{array}{c}\text { ALA (mg/L) } \\
\text { n.r. } \leq 7.5\end{array}$ & $\begin{array}{c}\text { PBG }(\mathrm{mg} / \mathrm{L}) \\
\text { n.r. } \leq 2.5\end{array}$ & $\begin{array}{c}\text { Total Porphyrins } \\
(\mu \mathrm{g} / \mathrm{g} \text { Creatinine) } \\
\text { n.r. } \leq 200\end{array}$ & HMBS Activity ${ }^{2}$ & Mutation $^{3}$ & Location & Reference \\
\hline $\mathrm{P} 1(\mathrm{~F}) 22$ & 60 & 47 & 22,025 & 105 & c. $33+5 G>C(\text { splicing defect })^{4}$ & Intron 1 & [19] \\
\hline P2 (F) 33 & 13 & 21 & 435 & 48 & c.41_42insA & Exon 3 & This study \\
\hline P3 (F) 29 & 114 & 104 & 1120 & 52 & \multirow{2}{*}{ c.76C > T (p.R26C) } & \multirow{2}{*}{ Exon 3} & \multirow{2}{*}{ [20] } \\
\hline P4 (F) 26 & 9 & 12 & 716 & 33 & & & \\
\hline P5 (F) 23 & 9 & 10 & 364 & 69 & c.107_110delACAG ${ }^{4}$ & Exon 4 & [21] \\
\hline P6 (F) 28 & 8 & 11 & 993 & 55 & c. $160+1 G>T$ (splicing defect $)^{4}$ & Intron 4 & [16] \\
\hline P7 (F) 45 & 14 & 39 & 234 & 62 & c.161-3C > G (splicing defect) & Intron 4 & This study \\
\hline P8 (F) 38 & n.a. & n.a. & n.a. & 75 & c.226_227delCT & Exon 6 & This study \\
\hline P9 (M) 62 & n.a. & n.a. & n.a. & 53 & c.275T > C (p.L92P) & Exon 7 & [22] \\
\hline P10 (F) 34 & 57 & 151 & 1926 & 61 & c.294G > T (p.K98N) & Exon 7 & This study \\
\hline P11 (F) 29 & n.a. & n.a. & n.a. & 47 & \multirow{2}{*}{ c.331G > A (p.G111R) } & \multirow{2}{*}{ Exon 7} & \multirow{2}{*}{ [23] } \\
\hline P12 (F) 61 & 20 & 35 & n.a. & 72 & & & \\
\hline P13 (F) 32 & n.a. & n.a. & n.a. & 50 & \multirow{3}{*}{ c.340insT } & \multirow{3}{*}{ Exon 7} & \multirow{3}{*}{ [24] } \\
\hline P14 (F) 38 & 73 & 21 & 23,381 & 57 & & & \\
\hline P15 (F) 21 & 37 & 41 & 1232 & 60 & & & \\
\hline $\mathrm{P} 16(\mathrm{~F}) 28$ & n.a. & n.a. & n.a. & 46 & c. $344+1 G>A$ (splicing defect $)^{4}$ & Intron 7 & [25] \\
\hline P17 (F) 46 & 67 & 45 & 910 & 60 & \multirow{3}{*}{ c.346C > T (p.R116W) } & \multirow{3}{*}{ Exon 8} & \multirow{3}{*}{ [26] } \\
\hline P18 (F) 19 & 17 & 47 & 392 & 48 & & & \\
\hline P19 (M) 25 & n.a. & n.a. & n.a. & 44 & & & \\
\hline P20 (F) 26 & 14 & 21 & 459 & 46 & c.423-1G > T (splicing defect) ${ }^{4}$ & Intron 8 & [27] \\
\hline P21 (F) 34 & 25 & 50 & 794 & 44 & \multirow{3}{*}{ c.517C > G (p.R173W) } & \multirow{3}{*}{ Exon 10} & \multirow{3}{*}{ [28] } \\
\hline P22 (F) 22 & 47 & 25 & 381 & 59 & & & \\
\hline P23 (F) 28 & 14 & 71 & 720 & 55 & & & \\
\hline
\end{tabular}


Table 1. Cont.

\begin{tabular}{|c|c|c|c|c|c|c|c|}
\hline Patient (Sex) Age ${ }^{1}$ & $\begin{array}{c}\text { ALA }(\mathrm{mg} / \mathrm{L}) \\
\text { n.r. } \leq 7.5\end{array}$ & $\begin{array}{c}\text { PBG }(\mathrm{mg} / \mathrm{L}) \\
\text { n.r. } \leq 2.5\end{array}$ & $\begin{array}{c}\text { Total Porphyrins } \\
\text { ( } \mu \text { g/g Creatinine) } \\
\text { n.r. } \leq 200\end{array}$ & HMBS Activity ${ }^{2}$ & Mutation $^{3}$ & Location & Reference \\
\hline P24 (F) 51 & n.a. & n.a. & n.a. & 70 & c.634A > G (p.M212V) & Exon 11 & [29] \\
\hline $\mathrm{P} 25(\mathrm{~F}) 17$ & 127 & 143 & 527 & 59 & c. $651+3 \mathrm{~A}>\mathrm{T}$ (splicing defect) & Intron 11 & This study \\
\hline P26 (F) 27 & 55 & 74 & n.a. & 58 & c.652-2delA (splicing defect) & Intron 11 & {$[30]$} \\
\hline $\mathrm{P} 27(\mathrm{~F}) 43$ & 10 & 5 & 669 & 71 & \multirow{11}{*}{ c.669_698del30 (p.E223_L232del) } & \multirow{11}{*}{ Exon 12} & \multirow{11}{*}[31]{} \\
\hline P28 (F) 26 & 30 & 7 & 316 & 55 & & & \\
\hline P29 (F) 36 & 38 & 156 & 1403 & 52 & & & \\
\hline P30 (F) 30 & 83 & 235 & 127 & 49 & & & \\
\hline P31 (M) 40 & 28 & 66 & 374 & 56 & & & \\
\hline P32 (F) 35 & n.a. & n.a. & 1578 & 44 & & & \\
\hline P33 (F) 56 & n.a. & n.a. & n.a. & 24 & & & \\
\hline P34 (F) 37 & n.a. & n.a. & n.a. & 54 & & & \\
\hline P35 (M) 38 & n.a. & n.a. & 358 & 58 & & & \\
\hline P36 (F) 41 & 10 & 4 & 908 & 64 & & & \\
\hline P37 (F) 62 & n.a. & n.a. & n.a. & 48 & & & \\
\hline P38 (F) 25 & 125 & 109 & 794 & 64 & c.673C > T (p.R225X) & Exon 12 & [20] \\
\hline P39 (M) 56 & n.a. & n.a. & n.a. & 61 & \multirow{2}{*}{ c.730_731delCT ${ }^{4}$} & \multirow{2}{*}{ Exon 12} & \multirow{2}{*}[32]{} \\
\hline P40 (F) 28 & n.a. & n.a. & n.a. & 60 & & & \\
\hline P41 (F) 49 & 55 & 103 & 1115 & 55 & c.741C > A (p.C247X) ${ }^{4}$ & Exon 12 & [24] \\
\hline $\mathrm{P} 42(\mathrm{~F}) 44$ & 31 & 31 & 524 & 65 & c.748_749insCATCGCTG ${ }^{4}$ & Exon 12 & [33] \\
\hline P43 (M) 37 & n.a. & n.a. & n.a. & 45 & c.771G $>$ A (splicing defect) ${ }^{4}$ & Exon12 & [34] \\
\hline P44 (F) 57 & n.a. & n.a. & n.a. & 57 & \multirow{3}{*}{ c.771 + 3_ +11del9 (splicing defect) } & \multirow{3}{*}{ Intron 12} & \multirow{3}{*}{ [17] } \\
\hline P45 (F) 36 & 21 & 28 & 801 & 48 & & & \\
\hline P46 (F) 20 & 13 & 26 & 973 & 55 & & & \\
\hline
\end{tabular}


Table 1. Cont.

\begin{tabular}{|c|c|c|c|c|c|c|c|}
\hline Patient (Sex) Age ${ }^{1}$ & $\begin{array}{c}\text { ALA (mg/L) } \\
\text { n.r. } \leq 7.5\end{array}$ & $\begin{array}{c}\text { PBG }(\mathrm{mg} / \mathrm{L}) \\
\text { n.r. } \leq 2.5\end{array}$ & $\begin{array}{c}\text { Total Porphyrins } \\
\text { ( } \mu \mathrm{g} / \mathrm{g} \text { Creatinine }) \\
\text { n.r. } \leq 200\end{array}$ & HMBS Activity ${ }^{2}$ & Mutation $^{3}$ & Location & Reference \\
\hline P47 (M) 42 & 41 & 124 & 608 & 65 & c.788_789delTG & Exon 13 & This study \\
\hline P48 (F) 41 & 19 & 68 & 11,258 & 55 & c.815_818delAGGA ${ }^{4}$ & Exon 13 & [35] \\
\hline P49 (F) 23 & 37 & 62 & 887 & 74 & \multirow{2}{*}{ c. $825+1 G>A$ (splicing defect) ${ }^{4}$} & \multirow{2}{*}{ Intron 13} & \multirow{2}{*}{ [36] } \\
\hline P50 (F) 28 & n.a. & n.a. & n.a. & 61 & & & \\
\hline P51 (F) 28 & 12 & 32 & 246 & 68 & c.835_837delACTinsG & Exon 14 & [29] \\
\hline P52 (F) 39 & 9 & 13 & 498 & 60 & c. $912+2 \mathrm{~T}>\mathrm{C}(\text { splicing defect })^{4}$ & Intron 14 & [37] \\
\hline P53 (F) 16 & 43 & 89 & 992 & 50 & c. $913-1 G>$ A (splicing defect) ${ }^{4}$ & Intron 14 & {$[38]$} \\
\hline P54 (M) 38 & 20 & 23 & 2264 & 53 & \multirow{2}{*}{ c. $973 \mathrm{C}>\mathrm{T}\left(\right.$ p.R325X) ${ }^{4}$} & \multirow{2}{*}{ Exon 15} & \multirow{2}{*}{ [39] } \\
\hline P55 (F) 30 & 38 & 146 & 1266 & 78 & & & \\
\hline
\end{tabular}

${ }^{1}$ Disease onset (years). Urinary precursors and porphyrin values at onset. Normal range: n.r. No data available: n.a. ${ }^{2}$ HMBS: erythrocyte hydroxymethylbilane synthase activity expressed as the percentage of the mean value from 50 healthy individuals (mean \pm standard deviation (SD): $98.5 \pm 14.2$ pmol uroporphyrinogen/hr/mg hemoglobin). ${ }^{3}$ The absence of these sequence deviations was confirmed in 50 unrelated healty (non-porphyric) individuals of Spanish origin. Reference sequence: GeneBank Accession number NM_O00190 (HMBS cDNA). ${ }^{4}$ Mutations previously unreported in the Spanish population. 


\subsection{Mutations Identified}

A total of 6 novel and 26 previously reported mutations were identified in these probands (Table 1). The novel mutations included a missense, an insertion, two deletions, and two splicing defects (Figures 3 and 4). Of the already known mutations, 14 were not previously reported in the Spanish population and 10 were found in more than one proband, the most frequent, identified in 11 patients as being c.669_698del30 (Table 1).

\section{(A) p.Lys98Asn}

\section{C}

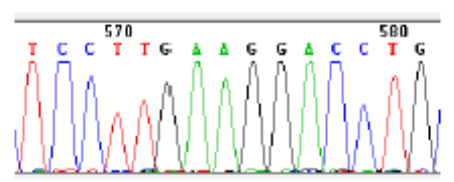

(B) c.41_42insA

C

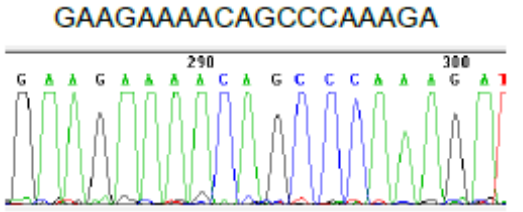

(C) c.226_227delCT

C

AGAAAAGCCTGTTTACCAAGGA

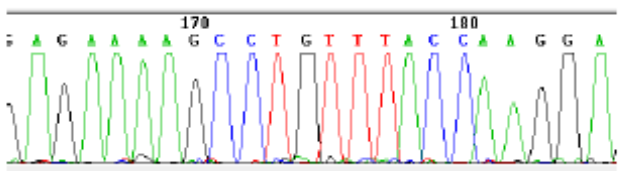

(D) c.788_789delTG

C

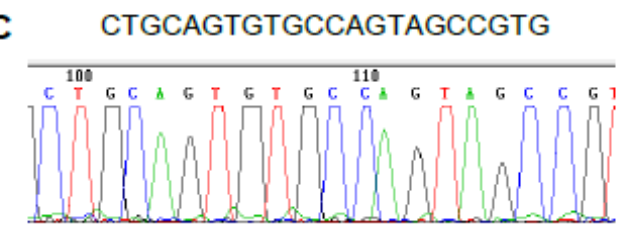

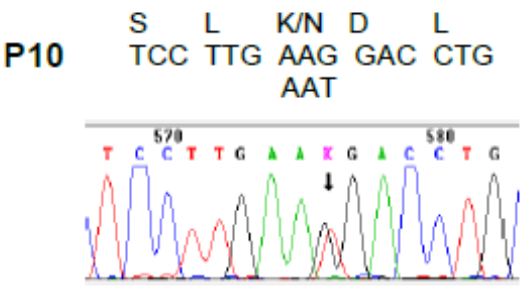

\section{P2}

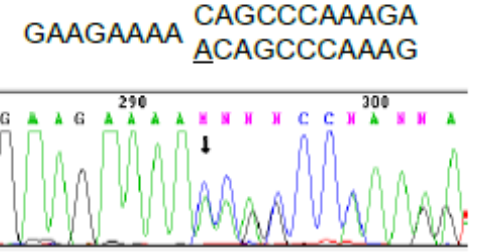

P8
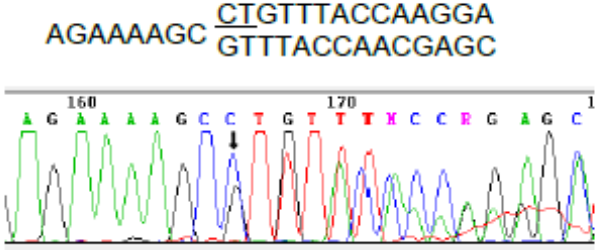

P47

TGCCAGTAGCCGTG

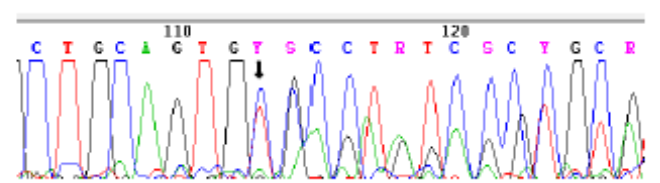

Figure 3. Novel exonic mutations in the HMBS gene. Electropherograms showing the relevant parts of the genomic sequence in a (C) control individual and in the (P) affected patients. (A) Missense mutation, the position of the mutated nucleotide is indicated by an arrow and the amino acid sequences are shown. (B) Small insertion, the arrow indicates the site of the insertion and the nucleotide inserted is underlined. (C,D): Small deletions, the arrow indicates the beginning of the deletion and the deleted nucleotides are underlined. Patients are numbered according to Table 1. 

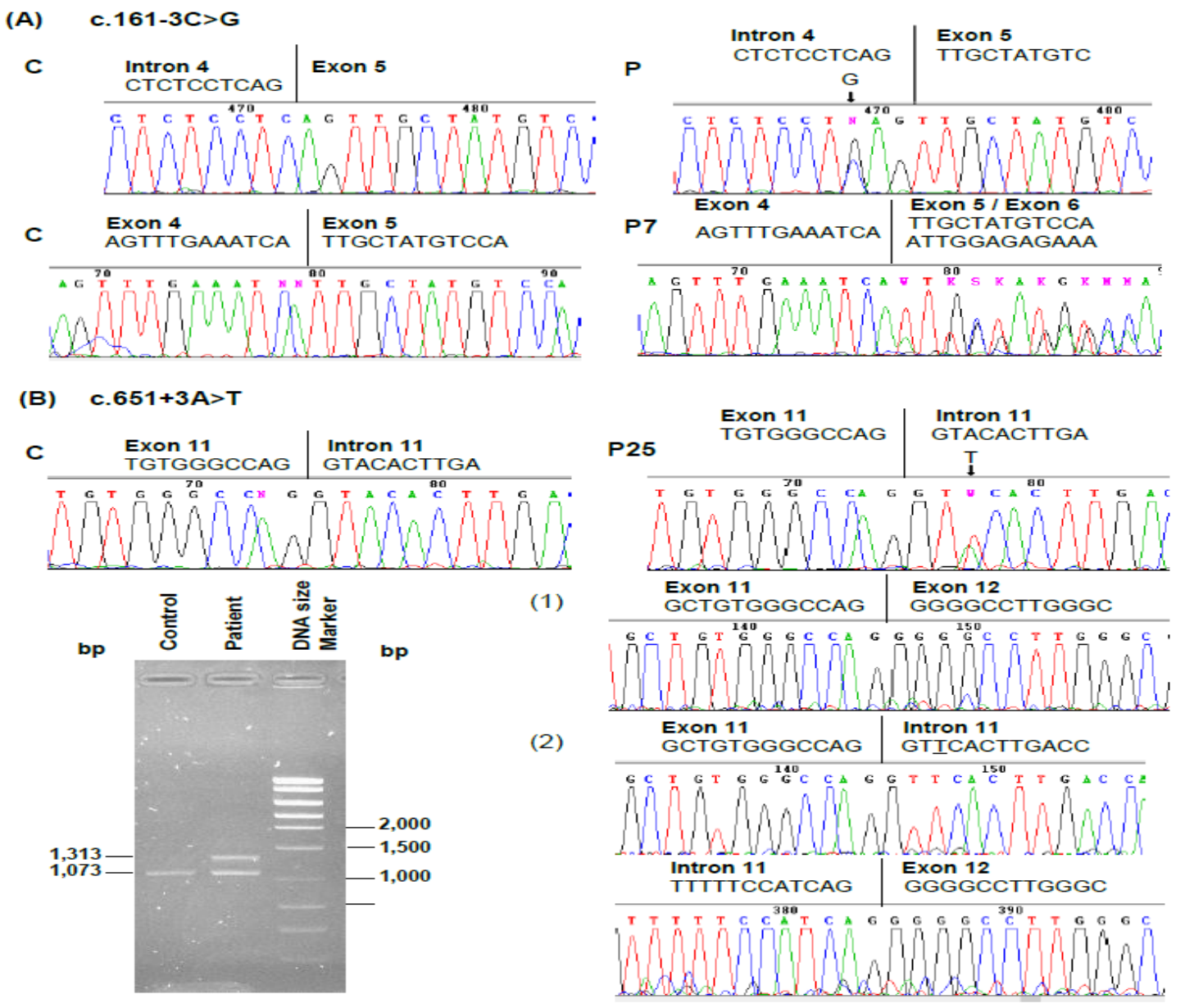

Figure 4. Characterization of the novel splice site mutations in the HMBS gene. Electropherograms showing relevant parts of the genomic and cDNA sequences in a $(C)$ control individual and in the $(P)$ affected patients. (A): Upper panel: Identification of the $\mathrm{G}$ to $\mathrm{C}$ transversion at the $3^{\prime}$ junction of intron 4 . The mutated nucleotide is indicated by an arrow. Lower panel: partial sequence electropherograms of the RT-PCR products from a control individual and from the patient. (B) Upper panel: Identification of the $\mathrm{A}$ to $\mathrm{T}$ transversion at the $5^{\prime}$ junction of intron 11 . The mutated nucleotide is indicated by an arrow. Lower panel: Agarose-gel electrophoresis of the HMBS RT-PCR products from a control individual and from the affected patient (left). Partial sequence electropherograms of the RT-PCR products from the patient (right), (1) a normal size product, and (2) a bigger product in which intron 11 has been retained. Patients are numbered according to Table 1.

The novel missense mutation was a transversion c.294G > T (p.K98N) in exon 7. This mutation expressed in E. coli rendered a residual activity of less than $1 \%$ of the wild-type HMBS activity. The insertion lies in exon 3 and consists of a single adenine insertion in a track of four adenines between positions c.38 and c.41, designated as c.41_42insA. This microinsertion causes a frameshift and introduces a stop signal of translation at codon 52, in exon 4 . The two deletions also caused a change in the reading frame with the introduction of a premature stop codon. These were microdeletions-a dinucleotide CT deletion of nucleotides c. 226 and c.227 in exon 6 (designated c.226_227delCT), which creates a stop of translation five codons downstream in the same exon. Finally, a dinucleotide GT deletion of nucleotides c.788 and c.789 in exon 13 (designated c.788_789delGT) resulted in a stop codon at position 289 in exon 14 .

Moreover, two novel splicing defects were identified. First, a $C$ to $G$ transversion in intron 4 , at the acceptor site (position c.161-3). RT-PCR and sequencing show that this defect results in the skipping of exon 5 (Figure $4 \mathrm{~A}$ ). The second was located in intron 11 and consisted of an $\mathrm{A}$ to $\mathrm{T}$ transversion at the 
donor site (position c.651 + 3). In this case, RT-PCR studies have shown that the mutation results in the retention of the entire 240 nucleotides of intron 11 in the mature transcript (Figure 4B).

\section{Discussion}

In this study, we measured the erythrocyte HMBS activity and performed a mutational analysis of the HMBS gene in 55 unrelated Spanish patients with AIP. Among these patients, one had the non-erythroid variant of AIP. In the patients studied, 32 different mutations were identified, of which 6 were novel mutations and 10 were found in more than one patient. The most frequent mutation was c.669_698del30, which was found in 11 patients. This is a previously described mutation that is common in Spain $[17,31]$. Of the reported mutations, 14 were found for the first time in the Spanish population.

The novel missense mutation p.K98N affects a residue that is invariant through evolution [2,3]. Lysine 98 is part of domain 1 of HMBS and interacts with the dipyrromethene cofactor at the active site [3]. Prokaryotic expression studies revealed that this change produces a protein with little, if any, residual activity. A previously identified disease-causing mutation at the same residue (p.K98R) had a similar activity when expressed in $E$ coli $[3,20]$.

Three novel frameshift mutations were found, namely, c.41_42insA, c.226_227delCT, and c.788_789delTG, which cause premature termination codons (PTCs) in exons 4, 6, and 13, respectively. Accordingly, the mutant transcripts are most likely degraded by nonsense-mediated mRNA decay (NMD) [40,41].

Two novel intronic mutations that affect consensus splice sites were found, namely: c.161-3C > G in the acceptor site of intron 4 (IVS4-3C > G) and c.651 + 3A>T in the donor site of intron 11 (IVS11 $+3 \mathrm{~A}>\mathrm{T}$ ). RT-PCR studies showed that both mutations cause aberrant splicing. The c.161-3C > G affects a conserved nucleotide in the intronic acceptor site sequence [42,43]. This mutation causes the deletion of the 50 nucleotides of exon 5 , which causes a change in the reading frame and introduces a stop codon after nucleotide 32. In the case of mutation c.651 $+3 \mathrm{~A}>\mathrm{T}$, a conserved purine nucleotide is replaced with a pyrimidine nucleotide within the splice donor site [42,43]. This mutation results in the retention of the 240 nucleotides of intron 11, an in-frame insertion that contains several stop codons. Intron 11 retention instead of exon 11 skipping is also the consequence of two other mutations at the same donor site, c.651 + 1G >C and c.651 + 2T > C [24,39]. As these splicing defects introduce PTCs, the mutant transcripts are a target for degradation by NMD [40,41].

In our series, no correlation between genotype-phenotype was observed, which is in agreement with previous studies $[37,38]$. Intragenic polymorphisms were studied elsewhere so as to establish a possible relation with clinical manifestation, however no association was found [37].

The identification of the mutation underlying the disease in these probands will allow for the accurate diagnosis of asymptomatic heterozygotes in their families, to provide counselling to those individuals, and to avoid precipitating factors of the disease. Furthermore, these results emphasize the molecular heterogeneity of AIP in Spain.

Author Contributions: Conceptualization, M.M.; formal analysis, M.-J.M.-J. and M.M.; funding acquisition, M.M.; investigation, M.-J.M.-J., M.-J.-B.C., F.J.-R., and M.M.; methodology, M.-J.M.-J., M.-J.-B.-C., F.J.-R., I.G.-P., S.D.-D., and M.M.; resources, F.-J.C.-F. and R.E.-d.-S.; writing (original draft), M.M.; writing (review and editing), F.-J.-C.-F., R.E.-d.-S., and M.M. All authors have read and agreed to the published version of the manuscript.

Funding: This research was supported by the Spanish grants from Instituto de Salud Carlos III (FIS PI15/01404), Fundación Mutua Madrileña de Investigación Médica (FMM 2013-0067), and Instituto de Investigación Sanitaria Hospital 12 de Octubre (imas12), programa de fomento I+D+I, proyectos de investigación clínica (2019-0040). F.J.R. had a contract financed by the "Consejeria de Educación, Juventud y Deporte de la Comunidad de Madrid" and the "Fondo Social Europeo, Unión Europea, Programa Operativo de Empleo Juvenil e Iniciativa de Empleo Joven (YEI)" (PEJ15/BIO/TL-0394). M.J.B.C. was supported by a grant from the Spanish Fundación Investigación Biomédica Hospital 12 de Octubre.

Acknowledgments: We are especially grateful to the patients and their families for their interest and cooperation in carrying out this study. We also thank the Genomics Unit facility of Instituto de Investigación Hospital 12 de Octubre.

Conflicts of Interest: The authors declare that there is no conflict of interest regarding the publication of this paper. 


\section{References}

1. Anderson, K.E.; Sassa, S.; Bishop, D.F.; Desnick, R.J. Disorders of heme biosynthesis: X-linked sideroblastic anemia and the porphyrias. In The Metabolic and Molecular Basis of Inherited Disease; Scriver, C.R., Beaudet, W.S., Valle, D., Eds.; McGraw-Hill: New York, NY, USA, 2001; pp. 2991-3062.

2. Gill, R.; Kolstoe, S.E.; Mohammed, F.; Al, D.B.A.; Mosely, J.E.; Sarwar, M.; Cooper, J.B.; Wood, S.P.; Shoolingin-Jordan, P.M. Structure of human porphobilinogen deaminase at 2.8 A: The molecular basis of acute intermittent porphyria. Biochem. J. 2009, 420, 17-25. [CrossRef] [PubMed]

3. Bung, N.; Roy, A.; Chen, B.; Das, D.; Pradhan, M.; Yasuda, M.; New, M.I.; Desnick, R.J.; Bulusu, G. Human hydroxymethylbilane synthase: Molecular dynamics of the pyrrole chain elongation identifies step-specific residues that cause AIP. Proc. Natl. Acad. Sci. USA 2018, 115, E4071-E4080. [CrossRef] [PubMed]

4. Bonkovsky, H.L.; Maddukuri, V.C.; Yazici, C.; Anderson, K.E.; Bissell, D.M.; Bloomer, J.R.; Phillips, J.D.; Naik, H.; Peter, I.; Baillargeon, G.; et al. Acute porphyrias in the USA: Features of 108 subjects from porphyrias consortium. Am. J. Med. 2014, 127, 1233-1241. [CrossRef] [PubMed]

5. Lamon, J.; With, T.K.; Redeker, A.G. The Hoesch test: Bedside screening for urinary porphobilinogen in patients with suspected porphyria. Clin. Chem. 1974, 20, 1438-1440. [CrossRef] [PubMed]

6. Elder, G.H.; Smith, S.G.; Smyth, S.J. Laboratory investigation of the porphyrias. Ann. Clin. Biochem. 1990, 27 Pt 5, 395-412. [CrossRef]

7. Anderson, K.E.; Bloomer, J.R.; Bonkovsky, H.L.; Kushner, J.P.; Pierach, C.A.; Pimstone, N.R.; Desnick, R.J. Recommendations for the diagnosis and treatment of the acute porphyrias. Ann. Intern. Med. 2005, 142, 439-450. [CrossRef]

8. Namba, H.; Narahara, K.; Tsuji, K.; Yokoyama, Y.; Seino, Y. Assignment of human porphobilinogen deaminase to 11q24.1-q24.2 by in situ hybridization and gene dosage studies. Cytogenet. Cell Genet. 1991, 57, 105-108. [CrossRef] [PubMed]

9. Yoo, H.W.; Warner, C.A.; Chen, C.H.; Desnick, R.J. Hydroxymethylbilane synthase: Complete genomic sequence and amplifiable polymorphisms in the human gene. Genomics 1993, 15, 21-29. [CrossRef] [PubMed]

10. Chretien, S.; Dubart, A.; Beaupain, D.; Raich, N.; Grandchamp, B.; Rosa, J.; Goossens, M.; Romeo, P.H. Alternative transcription and splicing of the human porphobilinogen deaminase gene result either in tissue-specific or in housekeeping expression. Proc. Natl. Acad. Sci. USA 1988, 85, 6-10. [CrossRef]

11. Grandchamp, B.; De Verneuil, H.; Beaumont, C.; Chretien, S.; Walter, O.; Nordmann, Y. Tissue-specific expression of porphobilinogen deaminase. Two isoenzymes from a single gene. Eur. J. Biochem. 1987, 162, 105-110. [CrossRef]

12. Song, G.; Li, Y.; Cheng, C.; Zhao, Y.; Gao, A.; Zhang, R.; Joachimiak, A.; Shaw, N.; Liu, Z.J. Structural insight into acute intermittent porphyria. FASEB J. 2009, 23, 396-404. [CrossRef] [PubMed]

13. Mustajoki, P. Normal erythrocyte uroporphyrinogen I synthase in a kindred with acute intermittent porphyria. Ann. Intern. Med. 1981, 95, 162-166. [CrossRef] [PubMed]

14. Nordmann, Y.; Puy, H. Human hereditary hepatic porphyrias. Clin. Chim. Acta 2002, 325, 17-37. [CrossRef]

15. Sassa, S. Modern diagnosis and management of the porphyrias. Br. J. Haematol. 2006, 135, 281-292. [CrossRef]

16. Puy, H.; Deybach, J.C.; Lamoril, J.; Robreau, A.M.; Da Silva, V.; Gouya, L.; Grandchamp, B.; Nordmann, Y. Molecular epidemiology and diagnosis of PBG deaminase gene defects in acute intermittent porphyria. Am. J. Hum. Genet. 1997, 60, 1373-1383. [CrossRef]

17. Mendez, M.; Moran-Jimenez, M.J.; Gomez-Abecia, S.; Garcia-Bravo, M.; Garrido-Astray, M.C.; Fontanellas, A.; Poblete-Gutierrez, P.; Frank, J.; Enriquez de Salamanca, R. Identification and characterization of HMBS gene mutations in Spanish patients with acute intermittent porphyria. Cell Mol. Biol. 2009, 55, 55-63.

18. Cormack, B. Mutagenesis of cloned DNA. In Current Protocols in Molecular Biology; Ausubel, F.M., Brent, R., Kingston, R.E., Moore, D.D., Seidman, J.G., Smith, J.A., Struhl, K., Eds.; John Wiley \& sons Inc.: New York, NY, USA, 2003; pp. 2851-8510.

19. Puy, H.; Gross, U.; Deybach, J.C.; Robreau, A.M.; Frank, M.; Nordmann, Y.; Doss, M. Exon 1 donor splice site mutations in the porphobilinogen deaminase gene in the non-erythroid variant form of acute intermittent porphyria. Hum. Genet. 1998, 103, 570-575. [CrossRef]

20. Kauppinen, R.; Mustajoki, S.; Pihlaja, H.; Peltonen, L.; Mustajoki, P. Acute intermittent porphyria in Finland: 19 mutations in the porphobilinogen deaminase gene. Hum. Mol. Genet. 1995, 4, 215-222. [CrossRef] 
21. Chen, B.; Solis-Villa, C.; Erwin, A.L.; Balwani, M.; Nazarenko, I.; Phillips, J.D.; Desnick, R.J.; Yasuda, M. Identification and characterization of 40 novel hydroxymethylbilane synthase mutations that cause acute intermittent porphyria. J. Inherit. Metab. Dis. 2019, 42, 186-194. [CrossRef]

22. Floderus, Y.; Shoolingin-Jordan, P.M.; Harper, P. Acute intermittent porphyria in Sweden. Molecular, functional and clinical consequences of some new mutations found in the porphobilinogen deaminase gene. Clin. Genet. 2002, 62, 288-297. [CrossRef]

23. Gu, X.F.; de Rooij, F.; de Baar, E.; Bruyland, M.; Lissens, W.; Nordmann, Y.; Grandchamp, B. Two novel mutations of the porphobilinogen deaminase gene in acute intermittent porphyria. Hum. Mol. Genet. 1993, 2, 1735-1736. [CrossRef] [PubMed]

24. Whatley, S.D.; Woolf, J.R.; Elder, G.H. Comparison of complementary and genomic DNA sequencing for the detection of mutations in the HMBS gene in British patients with acute intermittent porphyria: Identification of 25 novel mutations. Hum. Genet. 1999, 104, 505-510. [CrossRef] [PubMed]

25. Robreau-Fraolini, A.M.; Puy, H.; Aquaron, C.; Bogard, C.; Traore, M.; Nordmann, Y.; Aquaron, R.; Deybach, J.C. Porphobilinogen deaminase gene in African and Afro-Caribbean ethnic groups: Mutations causing acute intermittent porphyria and specific intragenic polymorphisms. Hum. Genet. 2000, 107, 150-159. [CrossRef] [PubMed]

26. Gu, X.F.; de Rooij, F.; Lee, J.S.; Te Velde, K.; Deybach, J.C.; Nordmann, Y.; Grandchamp, B. High prevalence of a point mutation in the porphobilinogen deaminase gene in Dutch patients with acute intermittent porphyria. Hum. Genet. 1993, 91, 128-130. [CrossRef]

27. De Siervi, A.; Mendez, M.; Parera, V.E.; Varela, L.; Batlle, A.M.; Rossetti, M.V. Acute intermittent porphyria: Characterization of two novel mutations in the porphobilinogen deaminase gene, one amino acid deletion (453-455delAGC) and one splicing aceptor site mutation (IVS8-1G>T). Hum. Mutat. 1999, 14, 355. [CrossRef]

28. Mgone, C.S.; Lanyon, W.G.; Moore, M.R.; Louie, G.V.; Connor, J.M. Identification of five novel mutations in the porphobilinogen deaminase gene. Hum. Mol. Genet. 1994, 3, 809-811. [CrossRef]

29. Solis, C.; Lopez-Echaniz, I.; Sefarty-Graneda, D.; Astrin, K.H.; Desnick, R.J. Identification and expression of mutations in the hydroxymethylbilane synthase gene causing acute intermittent porphyria (AIP). Mol. Med. 1999, 5, 664-671. [CrossRef]

30. Martinez di Montemuros, F.; Di Pierro, E.; Biolcati, G.; Rocchi, E.; Bissolotti, E.; Tavazzi, D.; Fiorelli, G.; Cappellini, M.D. Acute intermittent porphyria: Heterogeneity of mutations in the hydroxymethylbilane synthase gene in Italy. Blood Cells Mol. Dis. 2001, 27, 961-970. [CrossRef]

31. Guillen-Navarro, E.; Carbonell, P.; Glover, G.; Sanchez-Solis, M.; Fernandez-Barreiro, A. Novel HMBS founder mutation and significant intronic polymorphism in Spanish patients with acute intermittent porphyria. Ann. Hum. Genet. 2004, 68, 509-514. [CrossRef]

32. Mgone, C.S.; Lanyon, W.G.; Moore, M.R.; Louie, G.V.; Connor, J.M. Detection of a high mutation frequency in exon 12 of the porphobilinogen deaminase gene in patients with acute intermittent porphyria. Hum. Genet. 1993, 92, 619-622. [CrossRef]

33. Whatley, S.D.; Mason, N.G.; Woolf, J.R.; Newcombe, R.G.; Elder, G.H.; Badminton, M.N. Diagnostic strategies for autosomal dominant acute porphyrias: Retrospective analysis of 467 unrelated patients referred for mutational analysis of the HMBS, CPOX, or PPOX gene. Clin. Chem. 2009, 55, 1406-1414. [CrossRef] [PubMed]

34. Grandchamp, B.; Picat, C.; de Rooij, F.; Beaumont, C.; Wilson, P.; Deybach, J.C.; Nordmann, Y. A point mutation G-A in exon 12 of the porphobilinogen deaminase gene results in exon skipping and is responsible for acute intermittent porphyria. Nucleic Acids Res. 1989, 17, 6637-6649. [CrossRef] [PubMed]

35. De Siervi, A.; Rossetti, M.V.; Parera, V.E.; Astrin, K.H.; Aizencang, G.I.; Glass, I.A.; Batlle, A.M.; Desnick, R.J. Identification and characterization of hydroxymethylbilane synthase mutations causing acute intermittent porphyria: Evidence for an ancestral founder of the common G111R mutation. Am. J. Med. Genet. 1999, 86, 366-375. [CrossRef]

36. Llewellyn, D.H.; Scobie, G.A.; Urquhart, A.J.; Whatley, S.D.; Roberts, A.G.; Harrison, P.R.; Elder, G.H. Acute intermittent porphyria caused by defective splicing of porphobilinogen deaminase RNA: A synonymous codon mutation at $-22 \mathrm{bp}$ from the $5^{\prime}$ splice site causes skipping of exon 3. J. Med. Genet. 1996, 33, 437-438. [CrossRef] [PubMed] 
37. Surin, V.L.; Luchinina Iu, A.; Selivanova, D.S.; Pustovoit Ia, S.; Karpova, I.S.; Pivnik, A.V.; Luk'ianenko, A.V.; Kravchenko, S.K. Molecular genetic study of acute intermittent porphyria in Russia: Mutation analysis and functional polymorphism search in porphobilinogen deaminase gene. Genetika 2010, 46, 540-552. [CrossRef]

38. Cerbino, G.N.; Gerez, E.N.; Varela, L.S.; Melito, V.A.; Parera, V.E.; Batlle, A.; Rossetti, M.V. Acute intermittent porphyria in Argentina: An update. Biomed. Res. Int. 2015, 2015, 946387. [CrossRef]

39. Petersen, N.E.; Nissen, H.; Hansen, T.S.; Rasmussen, K.; Brock, A.; Horder, M. R325X mutation in exon 15 of the hydroxymethylbilane synthase gene identified in two Danish families with acute intermittent porphyria. Clin. Chem. 1996, 42, 106-107. [CrossRef]

40. Hentze, M.W.; Kulozik, A.E. A perfect message: RNA surveillance and nonsense-mediated decay. Cell 1999, 96, 307-310. [CrossRef]

41. Maquat, L.E. Defects in RNA splicing and the consequence of shortened translational reading frames. Am. J. Hum. Genet. 1996, 59, 279-286.

42. Burset, M.; Seledtsov, I.A.; Solovyev, V.V. Analysis of canonical and non-canonical splice sites in mammalian genomes. Nucleic Acids Res. 2000, 28, 4364-4375. [CrossRef]

43. Shapiro, M.B.; Senapathy, P. RNA splice junctions of different classes of eukaryotes: Sequence statistics and functional implications in gene expression. Nucleic Acids Res. 1987, 15, 7155-7174. [CrossRef] [PubMed]

(C) 2020 by the authors. Licensee MDPI, Basel, Switzerland. This article is an open access article distributed under the terms and conditions of the Creative Commons Attribution (CC BY) license (http://creativecommons.org/licenses/by/4.0/). 